\title{
Alberta Peregrine Falcon Recovery Plan 2004-2010
}
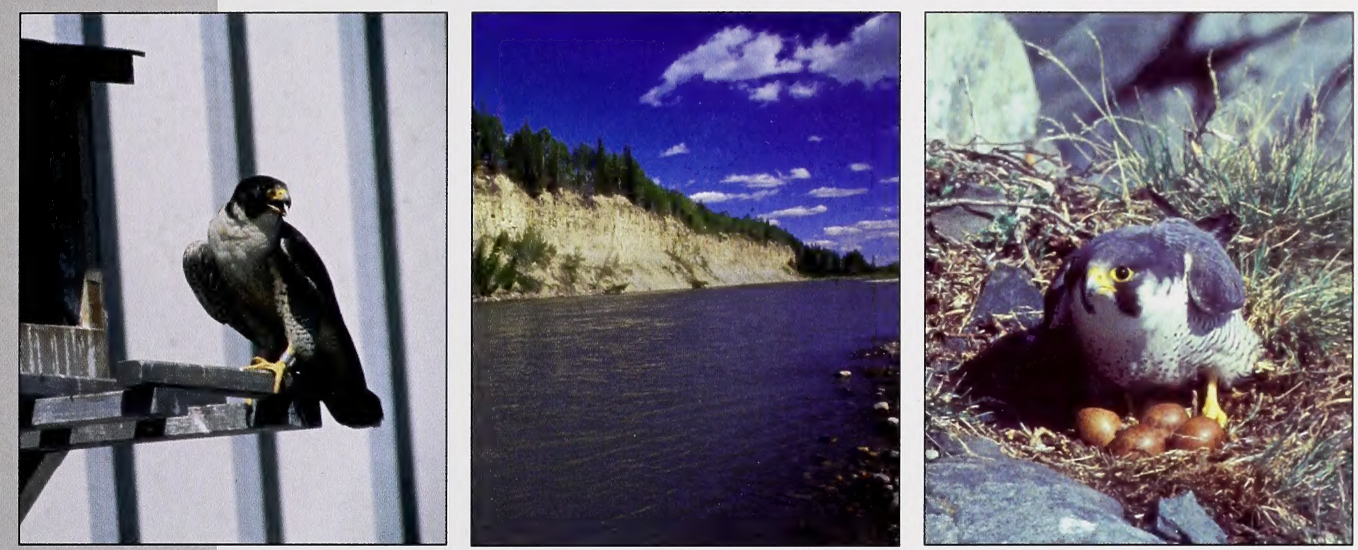

Alberta Species at Risk Recovery Plan No. 3

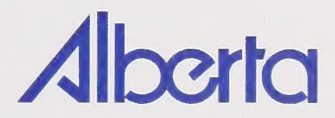


Digitized by the Internet Archive in 2016 


\title{
Alberta Peregrine Falcon Recovery Plan 2004-2010
}

\author{
Prepared by:
}

The Alberta Peregrine Falcon Recovery Team

Gordon Court (team leader), Alberta Fish and Wildlife Division Matt Besko, Alberta Fish and Wildlife Division Mark Bradley, Parks Canada

Rob Corrigan, Alberta Conservation Association

Geoff Holroyd, Canadian Wildlife Service David Prescott, Alberta Fish and Wildlife Division

Petra Rowell, Federation of Alberta Naturalists

February 2005

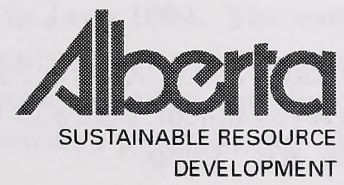


Publication No.:

ISBN: 0-7785-4054-5 (Printed Edition)

ISBN: 0-7785-4055-3 (On-line Edition)

ISSN: 1702-4897 (Printed Edition)

ISSN: 1702-4900 (On-line Edition)

Cover photos: Gordon Court

Information Centre - Publications

Alberta Sustainable Resource Development

Main Floor, Great West Life Building

9920 - 108 Street

Edmonton, Alberta, Canada T5K 2M4

Telephone: (780) 422-2079

E-mail: srd.infocent@gov.ab.ca

OR

Visit the Alberta Species at Risk Program web site at:

http://www3.gov.ab.ca/srd/fw/speciesatrisk/index.html

This publication may be cited as:

Alberta Peregrine Falcon Recovery Team. 2005. Alberta Peregrine Falcon Recovery Plan 20042010. Alberta Sustainable Resource Development, Fish and Wildlife Division, Alberta Species at Risk Recovery Plan No. 3. Edmonton, AB. 16 pp. 


\section{PREFACE}

Albertans are fortunate to share their province with a diverse variety of wild species.

Populations of most species of plants and animals are healthy and secure. However, a small number of species are either naturally rare or are now imperilled because of human activities. Recovery plans establish a basis for cooperation among government and stakeholders to ensure these species and populations are restored or maintained for future generations.

Alberta's commitment to the Accord for the Protection of Species at Risk and to the National Framework for the Conservation of Species at Risk, combined with requirements established under Alberta's Wildlife Act and the federal Species at Risk Act, has resulted in the development of a provincial recovery program. The overall goal of the recovery program is to restore species identified as Threatened or Endangered to viable, naturally self-sustaining populations within Alberta.

Alberta species at risk recovery plans are prepared under the supervision of the Fish and Wildlife Division, Alberta Sustainable Resource Development. These recovery plans are prepared by recovery teams composed of a variety of stakeholders including conservation organizations, industry, landowners, resource users, universities, government agencies and others. Membership is by invitation from the Director of Wildlife Management, and includes representation from the diversity of interests unique to each species and circumstance. Conservation and management of these species continues during preparation of the recovery plan.

Recovery plans include three main sections: background information that highlights the species' biology, population trends and threats; a recovery section that outlines goals, objectives, and strategies to address the threats; and an action plan that profiles priority actions required to maintain or restore the Threatened or Endangered species.

These plans are provided by the recovery team as advice to the Minister of Sustainable Resource Development (the Minister; the Department) and to all Albertans. The Department, other provincial departments, as appropriate, and Alberta's Endangered Species Conservation Committee review draft recovery plans, and provide recommendations to the Minister. In addition, an opportunity for review by the public is provided.

Approved plans are a summary of the Department's commitment to work with involved stakeholders to coordinate and implement conservation actions necessary to restore or maintain these species. Recovery plans are "living" documents and are revised as conditions change or circumstances warrant. Implementation of each recovery plan is subject to the availability of resources, from within and from outside government.

The Alberta Peregrine Falcon Recovery Plan 2004-2010 was reviewed by the Endangered Species Conservation Committee in June 2004. The committee subsequently recommended to the Minister that the plan be approved as written, and implemented. On September 27, 2004, the Minister approved the recovery plan and directed the Department to implement the plan to guide the continued recovery program for the peregrine falcon in Alberta. 
PREFACE iii

LIST OF FIGURES - v

ACKNOWLEDGEMENTS vi

EXECUTIVE SUMMARY vii

1.0 INTRODUCTION 1

1.1 Ministerial Conservation Action Statement 1

1.2 Recovery Team 1

2.0 SPECIES BIOLOGY 2

2.1 Breeding Biology 2

2.2 Population Distribution and Trends in Alberta 3

2.3 Habitat Requirements 5

3.0 LIMITING FACTORS 6

3.1 Pesticide Pollution 6

3.2 Falconry Harvest 7

3.3 Human Disturbance 8

4.0 RECOVERY STRATEGY 8

4.1 Technical and Biological Feasibility of Recovery ___ 8

4.2 Guiding Principles 9

4.3 Recovery Goal and Objectives 9

4.4 Strategy for Recovery 10

5.0 ACTION PLAN 10

5.1 Population Monitoring 10

5.2 Pesticide Monitoring 11

5.3 Information and Education 11

5.4 Research 11

5.5 Resourcing 11

5.6 Plan Management and Administration 11

6.0 IMPLEMENTATION SCHEDULE AND COSTS 12

7.0 SOCIO-ECONOMIC CONSIDERATIONS 13

8.0 REFERENCES 


\section{LIST OF FIGURES}

Figure 1. Historical nesting distribution for peregrine falcons in Alberta (prior to 1970). 4

Figure 2. Total number of occupied peregrine falcon territories in Alberta, 1970-2000. 5

Figure 3. Geometric mean levels of DDE in addled peregrine falcon eggs collected in Alberta1965 to 2002. 


\section{ACKNOWLEDGEMENTS}

The Alberta Peregrine Falcon Recovery Team thanks its respective organisations for providing in-kind support for the preparation of this plan. Funding from the Species at Risk Program of Alberta Sustainable Resource Development supported the preparation of the Alberta Peregrine Falcon Recovery Plan. 


\section{EXECUTIVE SUMMARY}

The peregrine falcon (Falco peregrinus anatum) formerly nested along the banks of most major rivers in Alberta (Court 1993a). Like most populations in North America, Alberta peregrines suffered reproductive failure and population declines in the 1950s and 1960s associated with the widespread and indiscriminate use of organochlorine pesticides, most notably DDT (Court 1993b, Court et al. 1996). Over 100 different historical nesting locations have been documented in natural settings in the province (Court 1993a, Fish and Wildlife Division and Canadian Wildlife Service, unpubl. data), however the first province-wide survey in 1970 (Cade and Fyfe 1970) revealed the existence of only a single productive pair. Since then, captive-breeding programs (Fyfe 1976) and re-introductions (Holroyd and Banasch 1990) have re-established a provincial population now estimated at between 45 and 55 territorial pairs (Corrigan 2000, Rowell et al. 2003). Presently, the peregrine falcon is listed as a Threatened species in both Alberta (following review by Alberta's Endangered Species Conservation Committee) and Canada (following review by the Committee on the Status of Endangered Wildlife in Canada (COSEWIC 2001).

In Alberta, peregrine pairs are widely dispersed, but occur in two main populations. The Northern Alberta population occurs north of Lake Athabasca and west into Wood Buffalo National Park. The Southern Alberta population is generally considered to consist of pairs nesting south of 56 degrees north latitude. Key breeding sites within the Southern Population include: Edmonton, Calgary, Wabamum Lake, and the Red Deer River. Six major surveys for the species have been conducted since 1970. In the year 2000, 23 territorial pairs were located in the Southern Population and 25 territorial pairs were counted in the Northern Population (Corrigan 2000, Rowell et al. 2003).

In 2000, the peregrine was down-listed from Endangered to Threatened in Alberta in recognition of an increasing population, a measured reduction in pesticide residues in tissues, and demonstrated improvements in reproductive performance. Along with this change in listing, the Minister of Environment (now Sustainable Resource Development) accepted an Initial Conservation Action Statement from the Endangered Species Conservation Committee that recommended further recovery actions in the province. This included the formation of a multistakeholder Recovery Team whose role is to advise the Minister on all matters relating to peregrine falcon conservation in the province, and preparation of a Recovery Plan. The Alberta Peregrine Falcon Recovery Plan was produced to embrace the objectives of the Ministerial Initial Conservation Action Statement.

Recovery goals for Alberta are based on population, pesticide contaminant, and productivity targets derived from historical data and on an understanding of threshold levels for 'healthy' peregrine populations. These goals are:

(1) To achieve a well-distributed, average population of 70 territorial pairs of peregrine falcons in Alberta by 2010;

(2) To monitor pesticide contaminants in non-viable peregrine falcon eggs in the province to ensure that geometric mean levels of the residue DDE remain below $7.5 \mathrm{mg} / \mathrm{kg}$ (parts per million) over the long-term; and 
(3) To employ all management techniques possible to achieve a mean fledging rate of greater than 1.25 young/territorial pair/year in the province over the long-term.

The overall cost of the actions detailed in the Recovery Plan is no more than $\$ 10,000$ per year, including both cash and 'in-kind' support. Cost during National Survey Years (2005 and 2010) will be higher. A variety of agencies will be invited to participate in the funding and implementation of recovery initiatives. 


\subsection{INTRODUCTION}

\section{$\underline{1.1 \text { Ministerial Conservation Action Statement }}$}

In November 1999, the Minister of Environment (now Sustainable Resource Development), on recommendation from Alberta's Endangered Species Conservation Committee (ESCC), approved the down-listing of the peregrine falcon from Endangered to Threatened in Schedule 6 of the Wildlife Regulation (AR 143/97). The status revision was based on documented increases in the provincial peregrine population, increases in natural rates of productivity, and reduction in the average body burden of organochlorine pesticide residues (most notably those of DDT) in falcons nesting in Alberta. The action statement specified that a Recovery Plan would be prepared and that all those with a stake in peregrine issues should be invited to participate in recovery planning, and that sufficient new resources should be made available to support essential conservation actions. Furthermore, the action statement called for immediate support for the 2000 peregrine falcon survey and commitment to monitoring and supplementation of peregrine nests in southern Alberta. The Alberta Peregrine Falcon Recovery Plan was constructed to embrace these, and all other directives of the ministerial conservation action statement.

\section{$\underline{1.2 \text { Recovery Team }}$}

The Alberta Peregrine Falcon Recovery Team was initiated by the Minister of Sustainable Resource Development, and receives operational guidance and approval from the Director of Wildlife Management, Fish and Wildlife Division, SRD. The Team's primary responsibility is to facilitate and co-ordinate the conservation and recovery of this species in Alberta. It provides expert advice to the Minister (or his delegate) on all matters relating to the management of peregrine falcons in Alberta. The Team is also responsible for writing, updating, and guiding the implementation of the provincial Recovery Plan, and for providing input to the National Anatum Peregrine Falcon Recovery Team on matters relating to peregrine management in Alberta. This provincial Team will not always implement the planned actions directly, although Team members and/or the organisations they represent will participate in many of the planned activities. The Team will encourage and facilitate the involvement of all interested parties in the recovery of peregrine falcons in the province when possible, and will periodically report on the progress of the recovery program.

Because of the multi-stakeholder nature of recovery issues, Team membership will remain dynamic and strive for the best representation of all affected parties. The Team will meet at least once annually and currently consists of the following members: Alberta Conservation Association, Fish and Wildlife Division - Alberta Sustainable Resource Development, Canadian Wildlife Service - Environment Canada, Parks Canada (Wood Buffalo National Park), and the Federation of Alberta Naturalists. 


\subsection{SPECIES BIOLOGY}

\section{$\underline{2.1 \text { Breeding Biology }}$}

The peregrine falcon (Falco peregrinus) is a sleek, compact, and powerful bird of prey; males are roughly the size of an American crow (Corvus brachyrhychos) while females are slightly smaller than a common raven (Corvus corax). Three subspecies are recognised in North America; two of which, F.p. anatum and F.p. tundrius, occur in Alberta. Tundrius peregrines migrate through Alberta in the spring and fall; only birds recognised as F.p. anatum breed in the province. Both of these subspecies are migratory and Alberta breeding birds have been recovered during winter as far south as Brazil. Other band returns and recent satellite telemetry data indicate that Alberta peregrines usually winter as far north as Mexico (Stepnisky 1998, G. L. Holroyd, unpubl. data). Although mid-winter records of peregrine falcons exist from Red Deer and Calgary (Fish and Wildlife Division, unpubl. data), only on one occasion has a peregrine been documented spending the entire winter in Alberta: an adult female over-wintered at a nest site Edmonton in 2001 (Fish and Wildlife Division, unpubl. data).

In Alberta, peregrine falcons arrive on the breeding territories in late March and early April. Arrival time is independent of sex. Pairs advertise their territory and pair bond through a combination of aerial and nest ledge displays. Territorial defence against conspecifics is usually sex specific and can involve violent combat and occasionally fatality of combatants. Clutches usually contain four eggs, but clutches of five have been recorded on three occasions in Alberta (Fish and Wildlife Division, unpubl. data). The earliest recorded date for clutch initiation is April 26; the latest clutch initiation for Alberta was estimated to be 12 to 14 June (Fish and Wildlife Division, unpubl. data). Incubation of eggs is shared by both sexes and lasts 28 to 33 days (Ratcliffe 1993). Young fledge at 40 to 46 days of age (Cade 1982), with juvenile males usually fledging before females. Most birds leave the Canadian prairies for wintering grounds by the end of the first week in October (Fish and Wildlife Division, unpubl. data).

Females are capable of breeding at one year of age, but are most often recruited as breeding birds at two years of age. Most males begin breeding at age three (Stepnisky 1998). Reproductive success of peregrine falcons in Alberta is highly variable from year to year; severe weather events appear to exert the greatest influence on annual reproductive success. An average fledging success of about 1.5 young/pair has been recorded in Alberta over the last two decades and estimates of recruitment rates range between 8 and 11\% (Court 1994, Stepnisky 1998). Management of pairs (fostering captive raised young) over the last two decades has bolstered productivity to over 2.0 young per pair in some years; the populations both in southern Alberta and northern Alberta have experienced strong growth under such management. Natural productivity goals for most peregrine recovery plans in the United States and Canada range between 1.25 and 1.5 young per territorial pair (Millsap et al. 1998).

Estimates of annual mortality for adult peregrines range from a minimum of $16 \%$ to a maximum of $32 \%$ (Court 1994, Stepnisky 1998), though pre-breeding mortality of young peregrines is considerably higher. Recruitment rate for the Southern Alberta population has been estimated at $11 \%$ (Stepnisky 1998). Young birds have been known to disperse from Alberta to sites over 
$1800 \mathrm{~km}$ away (Fish and Wildlife Division, unpubl. data); conversely, birds fledged from as far away as $1200 \mathrm{~km}$ have settled at breeding territories in Alberta (Stepnisky 1998).

\subsection{Population Distribution and Trends in Alberta}

In Alberta, peregrine falcon breeding sites are widespread, with most natural nest sites confined to the banks of rivers throughout the province, or on cliffs overlooking lakes in the Canadian Shield region. Historical nest sites (i.e., documented prior to 1970) are very rare in the mountain and foothills region (one record, Fish and Wildlife Division, unpubl. data) and rare on the prairies (fewer than 10 records, Court 1993a) (Figure 1). Most historical nest sites and presently occupied sites occur in the Parkland, Boreal, and Canadian Shield regions. A total of 115 natural historical nesting locations are known for Alberta. However, it is important to note that an inventory of breeding pairs on potential nesting habitat was never performed in a systematic manner before the species disappeared from the province in the 1960s (Fish and Wildlife Division, Canadian Wildlife Service, unpubl. data), so it is impossible to know the size of the Alberta population in pre-pesticide times.

Peregrine falcons have bred at 16 urban/industrial sites in Alberta (Fish and Wildlife Division, unpubl. data); all such records were made subsequent to the re-introduction of captive-raised birds (i.e., after 1975, see below). For management purposes, two populations are now recognized in Alberta. The Northern Alberta population occurs north of Lake Athabasca and west into Wood Buffalo National Park; the Southern Alberta population is generally considered to consist of pairs nesting south of 56 degrees north latitude. Centres of concentration for the Southern Population include Edmonton, Calgary, Wabamum Lake, and the Red Deer River.

Following widespread concern over the decline of peregrine falcon populations in North America and elsewhere (Hickey 1969), efforts were made to systematically inventory peregrine falcon populations in Canada and the United States every five years. Upon the completion of the first of these surveys in 1970 (Cade and Fyfe 1970), only a single productive peregrine falcon pair was found in Alberta. The second such inventory (Fyfe et al. 1976) was to document the extirpation of the peregrine falcon in Canada south of the boreal forest and east of the Rocky Mountains; in that survey year only three pairs made up the Alberta population. Five major peregrine falcon surveys have been conducted in Alberta since 1975; results of these surveys are summarized in Figure 2.

The Canadian Wildlife Service (Fyfe 1976) initiated active management of anatum peregrine falcons in Canada in the early 1970s, with the assembly of captive breeding stock at Wainwright, Alberta. Re-introduction of captive-raised young, either by fostering to wild pairs or by hack releases, was initiated in the mid-1970s and continued in Alberta until the late 1990s (Holroyd and Banasch 1990, Rowell and Stepnisky 1997, Stepnisky 1998). Despite release efforts in the 1970s and 1980s, the Alberta population did not experience strong recovery until the early 1990s (Rowell and Stepnisky 1997, Stepnisky 1998) (Figure 2). A detailed status report produced in 1997 (Rowell and Stepnisky 1997) documented 19 territorial pairs in the Southern Population and 15 pairs in the Northern Population in that year. Of the birds in the south, $65 \%$ were known to have originated as captive-raised released birds (Rowell and Stepnisky 1997). Data on origin were poorer for the Northern Population, but an estimate of the proportion of captive-raised birds 
in the breeding population in 1997 was approximately $20 \%$. The proportion of unbanded birds in the population suggested that the effects of immigration on the recovery of this population were significant (Rowell and Stepnisky 1997). Recent analysis of the banding status of adult peregrines in Alberta's Southern Population has shown that approximately $95 \%$ of the genetic diversity that existed in the founding (i.e., captive breeding) population still exists in the reestablished wild population (Stepnisky 2000); a similar analysis for the Northern Population has not been attempted.

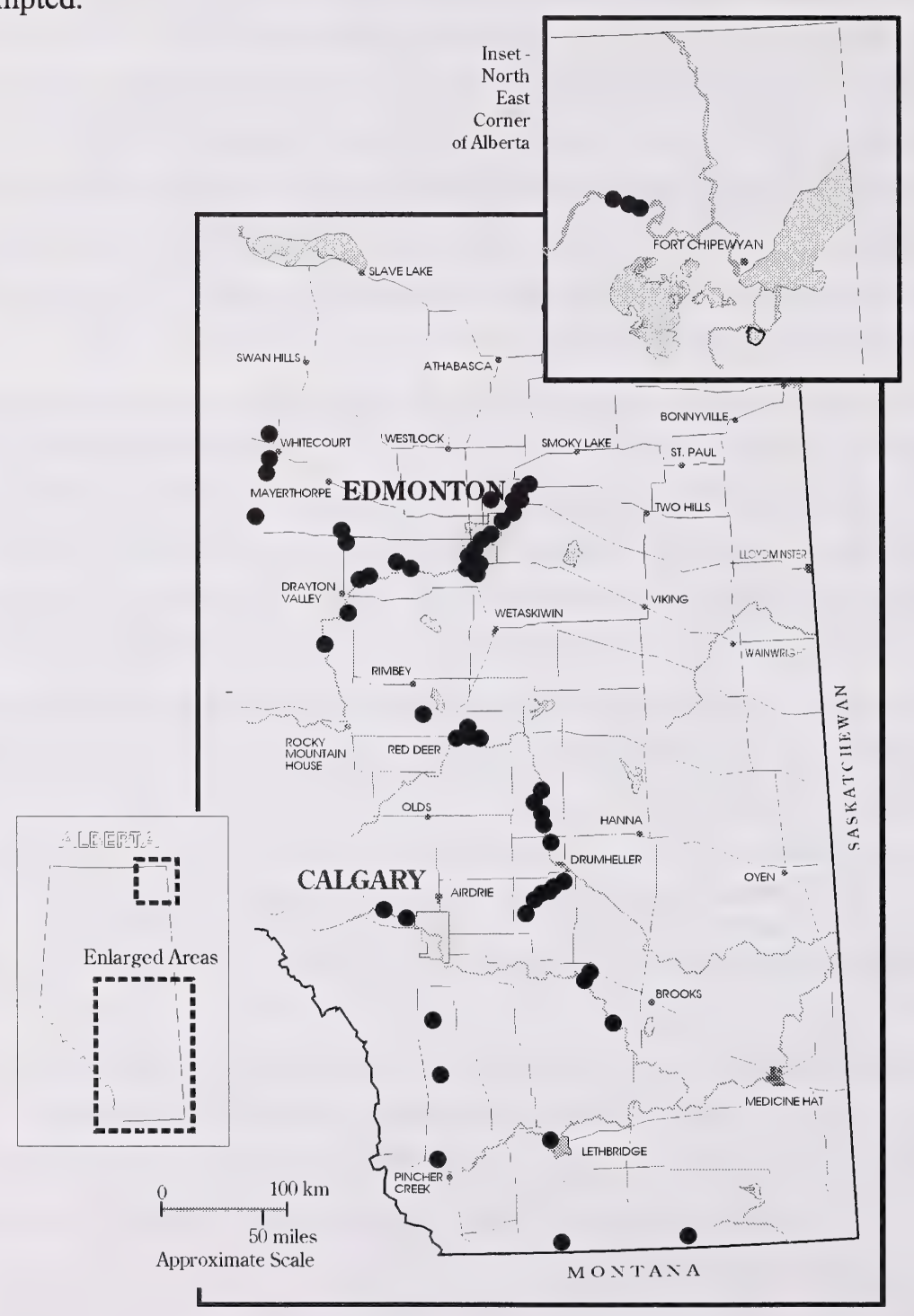

Figure 1. Historical nesting distribution for peregrine falcons in Alberta prior to 1970 (from Rowell and Stepnisky 1997). 
The last province-wide survey for peregrine falcons was performed in 2000. In that year, 23 territorial pairs were located in the Southern Population and 25 territorial pairs were counted in the Northern Population (Figure 2) (Corrigan 2000, Rowell et al. 2003). Since 2000, monitoring of known breeding pairs in the Southern Population has occurred on an annual basis (Fish and Wildlife Division/Alberta Conservation Association, unpubl. data); a sample of the breeding pairs in the Northern Population has also been monitored each year. Data from these years suggest that both populations are about the same size as reported in 2000 .

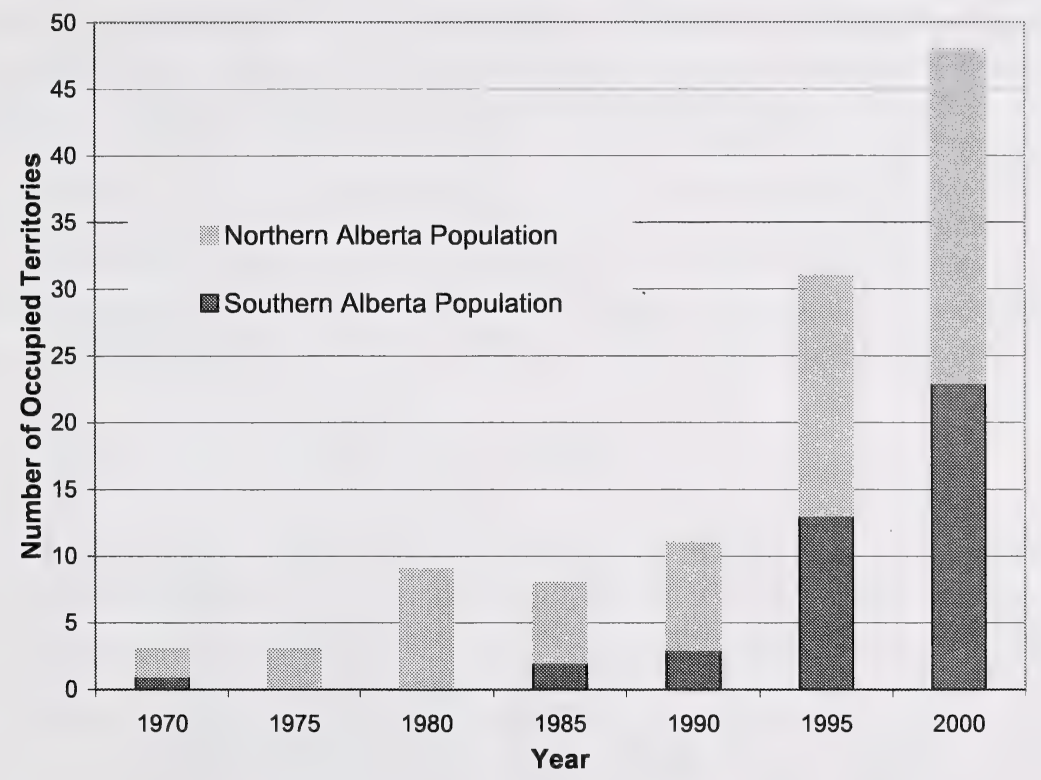

Figure 2. Total number of occupied peregrine falcon territories in Alberta, 1970-2000 (from Corrigan 2000)

\section{$\underline{2.3 \text { Habitat Requirements }}$}

The peregrine falcon is one of most widely distributed avian species in the world (Cade 1982). The species has been successful in establishing breeding populations in habitats as varied as the tropics, deserts, to tundra and it has nested on sites on the ground in the Arctic, to cliffs throughout its range, to man-made structures in the cores of some of the largest cities in the world. This flexibility is also matched in terms of diet, where the limits to the use of avian prey in any area are set only by size; arthropods and mammals are also used when abundant (White et al. 2002).

In Alberta, the peregrine has nested on cutbanks of major rives and streams, stone cliffs in the foothill and shield areas of the province, and on man-made structures. Therefore, nesting habitat must be considered abundant. The degree to which prey abundance may have changed in core habitat areas in recent decades is extremely difficult to evaluate. Peregrine falcons show such 
flexibility in prey use that it is impossible to say whether measured declines in some avian species would have an impact on peregrine numbers; these falcons tend to use whichever prey species are the most abundant in any given area (Ratcliffe 1993).

Considering the above, and the fact that the peregrine falcon did not decline because of habitat loss, it is challenging to attempt to define "critical habitat" for the peregrine falcon in Alberta, especially in the context of the federal Species At Risk Act (SARA; Statutes of Canada 2002). This topic was discussed by the National Anatum Peregrine Falcon Recovery Team during their 2003 meeting; the Team arrived at the following conclusion: "The team members present reviewed peregrine habitat requirements throughout the breeding season and found that only the peregrine's residence is easily defined with critical habitat being difficult to impractical to define" (National Peregrine Falcon Recovery Team 2003). This conclusion applies equally in Alberta. Historical nesting sites in the province (at least those that still exist) can be defined as "residences" under SARA. However, in terms of protections afforded to the species, there can be little gained from attempting to define "critical habitat" for this species, except to acknowledge that any habitat used by this species must be largely free of perpetual sources of organochlorine compounds (most notably DDT) if viable populations of the peregrine falcon are to exist.

\subsection{LIMITING FACTORS}

Limiting factors are considered to be those conditions that decrease nesting success of adult peregrines once they are established at a nesting territory, or those that reduce survivorship of young or adults. From a management standpoint, an understanding of these factors is important because they identify mechanisms through which peregrine falcon recovery can be sustained. The following limiting factors have been identified as affecting Alberta populations of peregrine falcons (Court 1993b, Court 1994, Rowell and Stepnisky 1997). Management actions that have been used to mitigate some of these factors are also listed, however, not all actions may be applicable or practical for peregrine falcon recovery in Alberta.

\section{$\underline{3.1 \text { Pesticide Pollution }}$}

The primary factor responsible for the decline of peregrine falcon populations in Alberta and elsewhere was reproductive failure following exposure to organochlorine pesticide pollutants. The link between eggshell thinning in birds of prey and organochlorine pollutants (primarily 1,1,1-trichloro-2,2-bis ( $p$-chlorophenyl) ethane or DDT) is unequivocal (synthesis in Cade et al. 1988 and Ratcliffe 1992). Pollutant status and reproductive dysfunction in peregrine falcons is well documented for populations in Canada in general (Berger et al. 1970, Court et al. 1990, Peakall et al. 1990, Johnstone et al. 1996) and in Alberta specifically (Court 1993b, Court et al. 1996). Data on DDE levels in peregrine eggs from Alberta show a clear downward trend over the last three decades (Court 1993b, Court et al. 1996; Figure 3), and improving reproductive success associated with declining pesticide pollutant residue levels is also well-documented in the province (Stepnisky 1998). Peregrine populations in Alberta (Rowell and Stepnisky 1997) and elsewhere have demonstrated sharp recovery as natural productivity has increased (Kiff 1988, Enderson et al. 1995, Millsap et al. 1998). 
Declining levels of organochlorine residues in Alberta peregrines and their prey leave little room for complacency. Although there are global initiatives in place to eliminate the manufacture and use of many of the most environmentally damaging compounds in this group, there exist strong lobbies that aim to resurrect chemicals like DDT as a short-term measure to control malaria and other insect-borne diseases in developing nations (Raloff 2000). As many of the peregrines in Alberta overwinter in Mexico, Central and South America, any move to resume DDT use on a large scale will be detrimental to these birds. Also, many new biocides are licensed for use each year in Canada and it is possible that there will be some that have unforeseen, negative effects on wildlife. It remains important for wildlife agencies to continue to monitor reproductive success of peregrines and to encourage routine residue scans of unhatched eggs to detect any sharp changes in either hatching success or chemical residues over time.

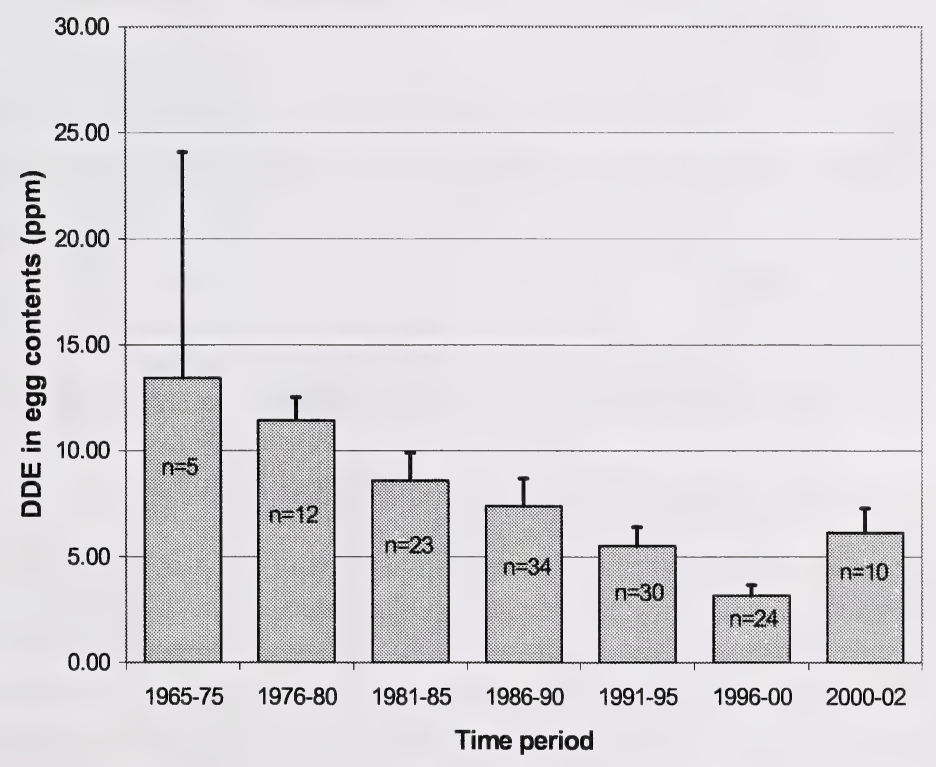

Figure 3. Geometric mean levels of DDE in addled peregrine falcon eggs collected in Alberta between 1965 and 2002.

\section{$\underline{3.2 \text { Falconry Harvest }}$}

Shortly after the proposal to remove the anatum peregrine falcon from the List of Endangered Species in the United States (Mesta et al. 1995), there arose proposals for re-instatement of regulations that would make it legal to harvest migrant peregrines (tundrius and anatum) for 'traditional' falconry use. This proposal was prepared by the U.S. Fish and Wildlife Service (Allen 2000) and is still under review. Subsequently, a document was commissioned to investigate if such a harvest was biologically sustainable, and to recommend acceptable biological and implementation criteria for this harvest (Taubert et al. 1999). 
This document has been reviewed by the Canadian Anatum Peregrine Recovery Team and was found wanting in several areas; it was not endorsed by the national Team. The primary problem with proposed harvest of passage (i.e., peregrines on their first migration) 'northern' peregrines, at least from an Alberta standpoint, is that there exists no way to guarantee that harvested birds are not taken from managed, recovering populations like those in Alberta, rather than from large, apparently stable populations from farther north. Until such assurances can be granted to provinces like Alberta, it is unlikely that jurisdictions in similar situations would endorse a harvest of passage birds.

\section{$\underline{3.3 \text { Human Disturbance }}$}

Peregrine falcons have proven remarkably adaptable to urban environments and, even when nesting in industrial settings, rarely experience enough disturbance from humans to cause reproductive failure. In most cases, the opportunity for serious nest disturbance of peregrines at both urban and rural sites will be obvious and requires relatively simple measures to avoid. Property managers at urban/industrial sites have been informed of critical times for nesting falcons (e.g., egg laying and fledging), when special attention may be necessary to avoid losses through disturbance. To date, education programs for such facility managers have been informal, yet very effective. Disturbance of wild nests, serious enough to cause nesting failure, is a relatively rare event in Alberta.

\subsection{RECOVERY STRATEGY}

\subsection{Technical and Biological Feasibility of Recovery}

The ultimate cause of the population decline in anatum peregrine falcons in Alberta, and elsewhere, was organochlorine pesticide pollution (Section 3.1). Subsequent restrictions on the manufacture and use of such compounds, combined with declining popularity of these chemicals in the third world, have created conditions at present that do not preclude the existence of healthy, viable populations of the peregrine in most parts of the world. Research in Alberta (Court 1993b, Court et al., 1996) has shown that environmental conditions are suitable for maintenance and growth of the present peregrine population in the province.

The efforts made to propagate peregrine falcons in captivity in North America are welldocumented (Cade et al. 1988) and the success of reintroduction of captive-raised birds in North America is unequivocal (Millsap et al. 1998. White et al. 2002). Alberta now has a population of between 40 and 50 pairs of birds, most of which have their origins in the captive stock originally archived in captivity by the Canadian Wildlife Service (Rowell and Stepnisky 1997, Stepnisky 2000). In an environment of declining levels of organochlorine pesticide pollutants, it is likely that the population of peregrine falcons in Alberta will continue to grow. There is nothing to suggest that there exist any technical or biological impediments to recovery of this species in the province. Moreover, there exist no 'knowledge gaps', in technology or about the biology of the species, which need to be addressed before recovery can be realized. 


\subsection{Guiding Principles}

It is important to acknowledge that there are a number of factors affecting recovery that are beyond the control of the Alberta Peregrine Falcon Recovery Team or this Recovery Plan. For example, the peregrine falcon's migratory nature and international life cycle requirements mean that the policies and actions of numerous governments and industries will to some extent impact the success of our recovery efforts. Regardless, it is the Recovery Team's belief, and our primary guiding principle, that recovery of the peregrine falcon population in Alberta is both possible and desirable.

The recovery and management of peregrine falcon in Alberta, will be guided by the following additional principles:

- The loss of key nesting habitat and individuals is unacceptable.

- A cooperative approach with landowners, industry and other agencies is essential.

- Management actions will employ tools resulting in the most immediate benefit to peregrine falcons and will be based on the best information available. However, implementation will not be delayed due to lack of specific supporting information.

- Landowners will not be impacted by the costs associated with maintaining or enhancing peregrine falcon nesting success.

- Activities will be restricted to a small number of effective and achievable actions.

- The recovery process will be guided by the notion of adaptive management, wherein specific actions are revisited and altered to ultimately improve the outcome.

\subsection{Recovery Goal and Objectives}

The general goal of the Alberta Peregrine Falcon Recovery Plan is to return the population of peregrine falcons in Alberta to a level approximating its estimated size before the introduction of organochlorine pesticide pollutants. Implicit to this goal is the need to monitor levels of pesticide pollutant exposure and natural productivity to ensure that the population is viable (i.e. self-sustaining or growing).

Recovery objectives for the Alberta peregrine falcon population are based on population, pesticide contaminant, and productivity targets derived from historical data and on an understanding of threshold levels for 'healthy' peregrine populations. These objectives are:

1. To achieve a well-distributed population of at least 70 territorial pairs of peregrine falcons in Alberta, by the year 2010;

2. To monitor pesticide contaminants in non-viable peregrine falcon eggs in the province to ensure that geometric mean levels of DDE remain below $7.5 \mathrm{mg} / \mathrm{kg}$ (parts per million) over the term of the recovery plan; and

3. To employ all management techniques possible to achieve a mean fledging rate of greater than 1.25 chicks/territorial pair/year in the province over the term of the recovery plan. 


\subsection{Strategy for Recovery}

The Alberta Peregrine Falcon Recovery Plan will serve for an initial period of seven years (2004-2010), and consists of six strategic areas, which will be pursued concurrently:

- Monitoring Population Performance: Includes all actions necessary to monitor population size and productivity annually, using a pre-determined sample of nests in northern Alberta and all presently occupied nest sites in southern Alberta.

- Pesticide Monitoring: Includes all actions necessary to obtain dead (addled) peregrine falcon eggs from any nest in Alberta, prepare such samples for pesticide residue analysis, and archive both shells and sample aliquots for future reference.

- Information and Education: Includes actions required to promote awareness and communication between the agencies responsible for the execution of the Recovery Plan and the stakeholders affected by peregrine falcon issues.

- Research: Includes all actions related to population and pesticide monitoring and evaluation of management actions in Alberta.

- Resourcing: Includes securing continued and future government, non-government and industry support for recovery efforts in the province.

- Plan Management and Administration: Includes operation of the Recovery Team, co-ordination/implementation of Recovery Plan, Recovery Plan evaluation/review and data management.

\subsection{ACTION PLAN}

The recovery actions outlined below form the basis of a seven-year plan aimed at achieving the three provincial recovery goals for Alberta.

\subsection{Population Monitoring}

5.1.1 A core number of nest sites will be visited every year to achieve an index of occupancy rates and breeding success, especially for years where no national/provincial peregrine falcon inventory is taking place. This involves all nests on man-made structures in the province and at least 10 natural sites in northern Alberta and at least 5 natural sites in southern Alberta.

5.1.2 Each year the Recovery Team will confirm which nests will be visited, the schedule of visits, and whether young will be banded at each.

5.1.3 Identify a Team member to receive data on occupancy, productivity, and banding each year.

5.1.4 Co-ordinate the survey of all known peregrine falcon nest sites in the province in the National Survey Years 2005 and 2010. As above, samples and data collected will be the responsibility of a designated Recovery Team member. 


\section{$\underline{5.2}$ Pesticide Monitoring}

5.2.1 Identify a Team member to receive all addled eggs and expedite contaminant and egg shell thickness analyses.

5.2.2 On each national survey year, review provincial pesticide contaminant data and include a summary with findings of population size and reproductive performance.

\section{$\underline{5.3 \text { Information and Education }}$}

5.3.1 Perform presentations on peregrine falcon related issues to technical and non-technical audiences.

5.3.2 Explore and put into practice methods of informing and educating owners/operators of industrial sites used by nesting peregrines to minimise activities that may negatively affect peregrine falcon recovery.

\section{$\underline{5.4 \text { Research }}$}

5.4.1 Conduct annual adult and brood surveys on a core of at least 25 peregrine territories each year.

5.4.2 As opportunities arise, participate with other agencies to deploy satellite telemetry on a limited number adults or juveniles in the Alberta population to discovery migration and wintering patterns. Priority for tracking will be birds known to be the most contaminated individuals in the population.

5.4.3 Continue with opportunistic banding, blood sampling for genetic analysis, reading of colour bands on adults, and compilation of observations of banded birds.

5.4.4 Compile and analyse information on productivity of peregrine pairs in the province to provide an on going evaluation of the need to modify existing management actions.

5.4.5 Participate in the National Peregrine Falcon Recovery Team meetings.

\section{$\underline{5.5 \text { Resourcing }}$}

5.5.1 Establish annual work plans and determine funding levels required to carry out recovery actions.

5.5.2 Approach government, non-government and industry partners to participate in or fund peregrine falcon recovery initiatives, both locally and provincially.

\subsection{Plan Management and Administration}

5.6.1 Convene the Alberta Peregrine Falcon Recovery Team a minimum of once annually and circulate results of these meetings to interested persons.

5.6.2 Monitor, assess and report on the progress of Recovery Plan actions annually, and develop new recovery strategies and actions when needed.

5.6.3 Co-ordinate monitoring of peregrine falcon populations in southern and northern Alberta.

5.6.4 Enter accumulated peregrine falcon nesting data into the Biodiversity/Species Observation Database (B/SOD) and other centralised databases following each field season. 


\subsection{IMPLEMENTATION SCHEDULE AND COSTS}

The following schedule outlines those activities identified as being important to peregrine falcon recovery by the Alberta Peregrine Falcon Recovery Team, and their associated costs (cash and 'in-kind') broken down by years when national surveys do not take place (base monitoring) and years when a full national peregrine survey is planned (full inventory). It is anticipated that a variety of agencies will participate in the funding and implementation of these activities.

\begin{tabular}{|c|c|c|c|c|c|}
\hline \multirow[b]{2}{*}{ Task No. } & \multirow[b]{2}{*}{ Activity } & \multirow[b]{2}{*}{ Lead Agency } & \multirow[b]{2}{*}{ Timelines } & \multicolumn{2}{|c|}{ Cost (S) } \\
\hline & & & & Non-survey & Survey \\
\hline 1 & Population Monitoring & & & & \\
\hline 5.1.1-5.1.4 & $\begin{array}{c}\text { Annual Monitoring or National } \\
\text { Surveys }\end{array}$ & $\begin{array}{c}\text { SRD/ACA/CWS } \\
\text { and WBNP }\end{array}$ & $\begin{array}{c}\text { Annual/5-year } \\
\text { interval }\end{array}$ & 15000 & 40000 \\
\hline 2 & Pesticide Monitoring & & & & \\
\hline 5.2 .1 & Chemical Analysis Eggs Contents & SRD & Annual & 3500 & 3500 \\
\hline 5.2 .2 & Pesticide Summary & SRD & 5-year interval & not done & 2000 \\
\hline 3 & Information and Education & & & & \\
\hline 5.3 .1 & $\begin{array}{l}\text { Presentations technical and non- } \\
\text { technical }\end{array}$ & All & Annual & 500 & 500 \\
\hline 4 & Research & & & & \\
\hline 5.4 .1 & Adult and brood surveys & As in \#2 & $\begin{array}{l}\text { Annual/5-year } \\
\text { interval }\end{array}$ & Included in \#2 & In \#2 \\
\hline 5.4 .2 & Satellite Telemetry & CWS & Annual if possible & $*$ & $*$ \\
\hline 5.4 .3 & Banding/Blood/Samples & As in \#2 & Annual & Included in \#2 & In \#2 \\
\hline 5.4 .4 & Analysis and Reporting & SRD/CWS/WBNP & 5-year interval & 1500 & 5000 \\
\hline 5.4 .5 & Participate in National Meetings & SRD/CWS & Annual & 3000 & 3000 \\
\hline 5 & Resourcing & & & & \\
\hline 5.5.1-5.5.2 & Solicit partnerships/funding & All & Annual & & 500 \\
\hline 6 & Plan Management/Administration & & & & \\
\hline 5.6.1-5.6.2 & Meetings & SRD & Annual & 500 & 500 \\
\hline 5.6 .3 & Co-ordinate Monitoring & SRD & Annual & 100 & 500 \\
\hline 5.6 .4 & Database Management & SRD & Annual & 500 & 500 \\
\hline
\end{tabular}

${ }^{+}$SRD: Sustainable Resource Development; ACA: Alberta Conservation Association; CWS: Canadian Wildlife Service; WBNP: Wood Buffalo National Park.

* Cost not identified as projects will take place when opportunities arise. 


\subsection{SOCIO-ECONOMIC CONSIDERATIONS}

The recovery actions for peregrine falcon in Canada were implemented more than three decades ago (Holroyd and Banasch 1990). Major expenditures by both government and non-government organizations on programs to effect recovery in Alberta, and elsewhere in the country, continued until the mid-1990s (Rowell and Stepnisky 1990, White et al. 2002). Fortunately, such actions met with considerable success and provincial and national recovery actions for the species now consist largely of monitoring efforts. Apart from the funding required of the government of Alberta to perform such work, there are few outstanding socio-economic issues in the province that need to be considered. Issues such as avoiding disturbance of nesting pairs at industrial/urban sites have been addressed successfully for more than two decades in Alberta. It is unlikely that these types of issues, even if unresolved or problematic, would preclude the recovery of the species in the province. 


\subsection{REFERENCES}

Allen, G. T. 2000. Draft environmental assessment: falconry take of migrant peregrine falcons in the contiguous United States and Alaska. Unpublished report prepared for the U.S. Fish and Wildlife Service. $28 \mathrm{pp}$.

Banasch, U. and G. L. Holroyd. In press. The 1995 Canadian peregrine falcon survey. Occasional Paper. Canadian Wildlife Service. ger, D. D., D. W. Anderson, J. D. Weaver, and R. W. Risebrough. 1970. Shell thinning in eggs of Ungava Peregrines. Canadian Field-Naturalist 84:265-267.

Cade, T. J. 1982. The Falcons of the World. Collins, London. 191 pp.

Cade, T. J. and R. W. Fyfe. 1970. The North American Peregrine Falcon Survey. Canadian Field Naturalist 84:231-245.

Cade, T. J., J. H. Enderson, C. G. Thelander and C. M. White. 1988. Their Management and Recovery. The Peregrine Fund, Inc., Boise, Idaho.

Corrigan, R. 2000. Survey of the Peregrine Falcon (Falco peregrinus anatum) in Alberta. Alberta Species at Risk Report No. 2. Alberta Sustainable Resource Development. $17 \mathrm{pp}$.

COSEWIC. 2001. Canadian Species at Risk, November 2001. Committee on the Status of Endangered Wildlife in Canada. $32 \mathrm{pp}$.

Court, G. S., C. C. Gates, D. A. Boag, J. D MacNeil, D. M. Bradley, A. C. Fesser, J. R. Patterson, G. B. Stenhouse and L. W. Oliphant. 1990. A toxicological assessment of peregrine falcons (Falco peregrinus tundrius) breeding in the Keewatin District of the Northwest Territories, Canada. Canadian Field Naturalist 104(2):255-272.

Court, G. S. 1993a. A review of historical nesting records for the American peregrine falcon (Falco peregrinus anatum) in Alberta south of $56^{\circ} \mathrm{N}$ : priorities for surveying a recovering population. Unpublished Report, Department of Environmental Protection, Fish and Wildlife Division, Government of Alberta. 70 pp.

Court, G. S. 1993b. A toxicological assessment of the American peregrine falcon (Falco peregrinus anatum) breeding in Alberta Canada - 1968 to 1992. Occasional Paper No. 10. Department of Environmental Protection, Fish and Wildlife Division, Government of Alberta. $28 \mathrm{pp}$.

Court, G. S. 1994. Population dynamics of American peregrine falcons (Falco peregrinus anatum) breeding in Northeastern Alberta, Canada - 1971 to 1993: an evaluation of the need for continued management. Occasional Paper No. 14. Department of Environmental Protection, Fish and Wildlife Division, Government of Alberta. 25 pp. 
Court, G. S., S. Brechtel, G. Erickson and B. Treichel. 1996. The future of the peregrine falcon (Falco peregrinus anatum) population in Alberta. Proceedings of the 4th Annual Prairie Endangered Species Conference. Lethbridge 1995. Pages 257-267.

Enderson, J. H., W. Heinrich, L. Kiff and C. M. White. 1995. Population changes in North American peregrines. Transactions of the North American Wildlife and Natural Resources Conference 60:142-161.

Fyfe, R. W. 1976. Rationale and success of the Canadian Wildlife Service peregrine breeding project. Canadian Field Naturalist 90:308-319.

Fyfe, R. W., S. A. Temple and T. J. Cade. 1976. The 1975 North American Peregrine Survey. Canadian Field Naturalist 90:228-273.

Hickey, J. J. (editor). 1969. Peregrine Falcon populations, their biology and decline. University of Wisconsin Press, Madison. 596 pp.

Holroyd, G. L. and U. Banasch. 1990. The reintroduction of the Peregrine Falcon, Falco peregrinus anatum, into southern Canada. Canadian Field-Naturalist 104(2): 203-208.

Johnstone, R. M., G. S. Court, A. C. Fesser, D. M. Bradley, L. W. Oliphant and J. D. MacNeil. 1996. Long-term trends and sources of organochlorine contamination in Canadian tundra peregrine falcons, Falco peregrinus tundrius. Environmental Pollution 93:109-120.

Kiff, L. F. 1988. Changes in the status of the Peregrine in North America: an overview. Pages 123 - 139 in Peregrine Falcon Populations - Their Management and Recovery. Edited by T. J. Cade, J. H. Enderson, C. G. Thelander and C. M. White, The Peregrine Fund, Inc., Boise, Idaho.

Mesta, R.T., T. Swem and S. Lawrence. 1995. Advance notice of a proposal to remove the peregrine falcon from the list of endangered and threatened wildlife. Federal Register 60:34406-34409.

Millsap, B. A., P. L. Kennedy, M. A. Byrd, G. S. Court, J. H. Enderson and R. N. Rosenfield. 1998. Review of the proposal to de-list the American peregrine falcon. Wildlife Society Bulletin 26:522-538.

National Peregrine Falcon Recovery Team. 2003. Minutes of the 2003 Meeting. Nova Scotia.

Peakall, D. B., D. G. Noble, J. E. Elliot, J. D. Somers and G. L. Erickson. 1990. Environmental contaminants in Canadian peregrine falcons Falco peregrinus: a toxicological assessment. Canadian Field-Naturalist 104:223-244.

Raloff, J. 2000. The case for DDT: What do you do when a dreaded environmental pollutant saves lives? Science News 158:12-14. 
Ratcliffe, D. 1993. The Peregrine Falcon (second edition). Poyser, London. 454 pp.

Rowell, P. and D. Stepnisky. 1997. Status of the peregrine falcon (Falco peregrinus anatum) in Alberta. Alberta Status Report Number 8. Wildlife Management Division, Government of Alberta. $24 \mathrm{pp}$.

Rowell, P., G. L. Holroyd, and U. Banasch. 2003. The 2000 Canadian peregrine falcon survey. Occasional Paper. Journal of Raptor Research 37:98-116.

Statutes of Canada. 2002. Bill C-5: An act respecting the protection of wildlife species at risk in Canada. Communication Canada-Canadian Government Publishing, Ottawa, Ontario, K1A 0S9.

Stepnisky, D. 1998. Demographic features of a recovering peregrine falcon (Falco peregrinus anatum) population in southern Alberta: 1980-1997. Alberta Environmental Protection, Wildlife Management Division, Occasional Report Series. No. 15. 27 pp.

Stepnisky, D. 2000. An evaluation of genetic concerns in a re-introduced population of American peregrine falcons (Falco peregrinus anatum) in southern Alberta. Thesis submitted for the Diploma in Endangered Species Management. Durrell Wildlife Conservation Trust International Training Centre, Jersey. 28 pp.

Taubert, B., J. Enderson, and B. Millsap. 1999. Biological criteria for a limited falconry harvest of peregrine falcon in the United States. Unpublished report prepared by the International Fish and Wildlife Agencies working group.

White, C. M, N. J. Clum, T. J. Cade and W. G. Hunt. 2002. Peregrine Falcon: The Birds of North America No. 660. Cornell Laboratory and the Academy of Natural Sciences. $48 \mathrm{pp}$. 


\section{List of Titles in the Alberta Species at Risk Recovery Plan Series}

(as of March 2005)

No. 1 Maintenance and Recovery Plan for Western Blue Flag (Iris missouriensis) in Canada. (2002)

No. 2 Alberta Piping Plover Recovery Plan 2002-2004. (2002)

No. 3 Alberta Peregrine Falcon Recovery Plan 2004-2010 (2005) 


\section{-}



